\title{
Final commentary: What is the Qur'ān?
}

\author{
Nora S. Eggen, University of Oslo
}

\section{Introduction}

There are numerous ways to describe the Qur'ān. Capturing its essence by way of definition, whether in form or content, has proven a perpetual challenge. From a cultural-religious perspective, the Qur'ān is habitually described as «the sacred book of Islam. In Islamic culture it is the Book. It represents a point of essential reference to the essence of Islamic culture and is referred to on a daily basis by believers, primarily as a religious guide, but also in everyday colloquial expressions» (Campanini, 2007, p. 1). This conceptual equation between the Qur'ān as a book and Islam as a particular religious culture is both common and commonsensical. However, while the Qur'ān certainly often materializes in the form of «a book», and while it undoubtedly is both revered and evoked by believers at different junctures in their spiritual and practical lives, this type of definition does not cater for the dynamics intrinsic to the text, its reception and its functionalities. ${ }^{1}$

A highly self-conscious text, a substantial portion of the Qur'ānic verses and passages address ontological, epistemological and methodological issues. In other words it is a pronounced metatextual record, with truth claims not only about God, the world and the human being in the world, but also about itself. It claims to be the word of God (kalām Allāh, Q 2:75), eternally preserved in heavenly spheres (Q 85:21-22; 43:4), mediated aural-orally by Prophetic recitation (qur'àn) and recorded in script (kitāb) (Q 12:1-2; 41:2-4; 43:2-4). The revelation (wahy and tanzil $Q$ 42:51; 26:192) consists in communicating utterances organized as units (signs: āyāt, Q 2:39;3:7), expressed linguistically in a particular language, Arabic, and meant for cognition (qur'ānan 'arabiyyan la 'allakum ta 'qilūn, Q 12:2; 43:3).

Some scholars call for historical anchoring of the Qur'ān in time and place as part of the common literary and historical legacy of Late Antiquity (Neuwirth, 2019, p. x). On the other side, the Qur'ānic disciplines ('ulūm al-Qur'ān) have developed a number of textual and hermeneutical tools to contextalize the text in view of the general and specific historical circumstances in which the text originated (asbāb al-nuzūl), as well as chronological developments within the Qur'ānic message, while acknowledging that both text and message cut across and rise above history (al-Zarkashī, 1994). As an historical event, the revelations Prophet Muhammad received were completed over a period of twenty-some years,

Corresponding author's email: n.s.eggen@teologi.uio.no

ISSN: 1457-9863

Publisher: Centre for Applied Language Studies

University of Jyväskylä

(C) 2019: The authors

http:/ /apples.jyu.fi

http://dx.doi.org/10.17011/apples/urn.201912185426 
after which a redaction into a formal codex (mușhaf) followed suit, as well the collection of a number of textual variants. Whereas the canonical text confirms with the aural-oral transmission as well as the written codex, the total corpus of Qur'ānic material includes both these widely accepted textual variants (qirä'āt mutawätira) and other, indefinite textual variants (qira' 'àt shädhdha). This built-in flexibility allows at times for interpretational latitude.

\section{Content}

The first word in what is traditionally considered the chronological order of revelation is the word iqra' (read: Q 96:1-5), presented as an imperative directed at the Prophet, and, by extension, any listener or reader. ${ }^{2}$ At the outset of the textual order of the codex, on the other hand, one of the main concepts evoked is guidance $(h u d \bar{a})$. In the very first chapter (sūra), al-Fātiha which takes the form of prayer with a first person voice belonging to the reader, the reader is asking for guidance (huda, Q 1:1). At the beginning of the next chapter, an answer to the prayer is given and a solution is offered: "This is the Scripture in which there is no doubt, containing guidance for those who are mindful of God..." 3 These two starting points of the text, then, each in their way contextualize the Qur'ānic role as a guiding tool to be engaged with. ${ }^{4}$ Among the many self-describing notions, al-furān conceptualizes (Q 25:1) the Qur'ān as a normative source providing moral advice and differentiating between right and wrong, while the polysemantic notion al-dhikr ( $Q$ 16:44) denote the manifold modes of thinking, remembering, and mentioning. Although the text comprises numerous genres and styles, the socalled verse of goodness (âyat al-birr Q 2:177) may conveniently illustrate three types of content in the Qur'ān; describing proper faith, proper behaviour, and proper attitude:

"Goodness (al-birr) does not consist in turning your face towards East or West. The truly good are those who believe in God and the Last Day, in the angels, the Scripture, and the prophets; who give away some of their wealth, however much they cherish it, to their relatives, to orphans, the needy, travellers ad beggars, and to liberate those in bondage; those who keep up the prayer and pay the prescribed alms; who keep pledges whenever they make them; who are steadfast in misfortune, adversary and times of dangers. These are the ones who are true, and it is they who are aware of God."

\section{Structure}

The Qur'ānic text is organized in chapters and verses of different length. Overall, the chronologically earlier revelations coincide with the later, and shorter, chapters in the textual order, and vice versa. The textual order of the codex, the muṣha $\bar{a}$, may be distinguished in three sections. The chapters in the first section are mostly compound both in terms of content and style, with longer verses, more complex arguments and more prescriptive content. The bulk of chapter in the middle consists to a large degree in narratives about earlier prophets and peoples. In the last section the content evolves around the profound realities of this world and the next, often expressed in metaphorical language and imagery. 
In addition to this structure of the textual order, and the chronological order, which is known from transmission of material on the historical situation of the revelations, there are also other, implicit structures in the text. For instance, narratives are often distributed throughout the text. Sometimes the same event is described with slight variations in different places, and at other times different aspects of the life of a particular person or people are found in different parts of the text. The narrative about Adam and his wife disobeying the Lord in the primordial garden is for instance told three times, with some slight differences opening for interpretational engagement (in assumed chronological order: 7:19$7: 26 ; 20: 120-128 ; 2: 34-39)$. Another example is the narratives about the prophet Ibrāhīm/Abraham, which is told in more than thirty-five disseminated passages.

At other times, the internal linking is formed by lexical, semantic or conceptual associative indexing. Often a notion or imagery is reiterated in different contexts providing new nuances of meaning, or a topic is presented from different angles. For instance, the Qur'ānic notion amāna is central to two partly overlapping conceptual fields, and at the cross-section of the vertical and the horizontal movements, the Divine covenant-trust (33:72) translate into trust as a socio-ethical value $(\mathrm{Q} 4: 58 ; 8: 27)$. Sometimes the text conceptually remodels an understanding from the pre- or extra-Qur'ānic context. In one verse, for instance, the understanding of the celebrated value of dignity is transformed from a worldly to a spiritual value (Q 49:13).

Although the Qur'ān may be read as a linear text, it is far from the only way to engage with it. Approaching the Qur'ān, in its original form or as translated text, can be challenging, because it in many ways defy our culturally grounded expectations to a text. It may be described as a helix, at every turn touching upon new elements of the same topics. Another way to describe this particular structural makeup is as a web of hypertextual references. These hypertextual features of the Qur'ān are epitomized to the fullest in the hâfiz, who, having preserved the entire corpus in his or her memory, is immersed into and by the text. Add to this the knowledge of the numerous traditions and disciplines born out of human engagement with the text; interpretation, translation, reception in art and literature, in intellectual discourse, academics, and polemics, an immense field of learning emerges, which no individual human is able to encompass in its totality.

\section{Interpretation}

On the receiving end of the Divine communication is always a listener-reader, whether he or she accepts the claims of the text or not. Numerous passages speak to the non-believers and to their rejection of the Qur'a an event and as message ( $Q$ $34: 31 ; 41: 26)$. For the believer, accepting the textual claims and committing to them constitute a meeting with the Divine presence. This is the plain conceptual content of the word Muslim: someone who submits to God (Eggen, 2016). Whether reciting the words in prayer (tartill, Q 73:4) or striving to understand them by study and reflection (tadabbur, Q 4:82), the believer understands the Qur'an to be a vehicle of Divine guidance, and reading as a devotional act to be conducted and implemented in the best possible way (fa-yattabi'üna ahsanahu, Q 39:18).

The form and content of the Qur'ānic communication are intrinsically interconnected. However, the prerogative for interpretational efforts is widely acknowledged in the Islamic traditions. The validity of the interpretation, on the 
other hand, is a question of linguistic, literary, and historical reasonability, and it is tied in with cultural, theological or ideological assumptions and implications. Throughout the history of Qur'anic reception, readers have been negotiating the text-internal truth claims and a host of methodological issues and hermeneutical techniques, tools and premises, with their own particular concerns, out of which is born a vast literary heritage in many languages. In translation, the unit of form and content, wording and meaning, is split in order for (at least some of the) meaning to be expressed in a new form, a new wording. Ontologically of a secondary order, a translated text must thus be considered an interpretation, together with other forms of exegetical efforts. ${ }^{5}$

\section{Qur'ānic literacy}

The Qur'a an is first and foremost language. There is a manifest aural-oral quality to the Qur'ānic text, both in terms of the primacy of the recited word, the transmission methods, and the textual structure, and in terms of the narrative and literary style of the text. It takes for instance both linguistic skills and audioliterary sensitivity to follow the sudden, and often unannounced, shifts in narrative voice and addressees or to identify the reference of the many pronouns. The art of memorization has continuously been a cornerstone in Islamic learning, but the written word, mediated in different forms, is essential. Historically, the nascent Islamic community increasingly appreciated reading and writing as educational, intellectual, and political tools.

Moreover, directly and indirectly, Qur'ānic language, concepts, ideas provide an inevitable frame of reference for the manifold symbol systems dominating Islamic traditions, and the common point of reference in a wider understanding of Islam as civilization. In this sense, the Qur'ān may be understood not only to be the foundational source text of Islamic tradition, but to be constitutive of the faith and tradition.

Literacy, both in the narrow sense of ability to decode script and in the wider sense of knowledge, insights and understanding in a particular field, is thus crucial to approaching the Qur' ānic discourse. Qur'ānic literacy may be defined as competence in language and text, as well as insights into the Qur'ān as a cultural artefact, as religious experience, and as intellectual tradition. There are many ways to approach the text and even if the reader is not fully cognizant of the breadth of this field, a minimum is to be aware of the existence of these functionalities and traditions.

The articles in this special issue aptly illustrate this complex from a number of perspectives. We learn about different ways Muslim children and young adults are introduced to and socialised into a hypertextual Qur'ānic culture where existential and ethical issues are articulated in a language which is simultaneously grounded in human experience and transcending it. These case studies provide linguistic, social and spiritual perspectives to how young people seek to draw out positive potentials in their faith and/or heritage culture. They also provide an insight into their coping strategies at a historical moment and in a context where these qualities are potentially negatively associated to social and political unrest and misgivings, and where a sense of belonging in existential and social terms is pivotal. 


\section{Endnotes}

1 See McAuliffe 2006, Rippin and Mojaddedi 2017 and Shah and Abdel Haleem 2019 for comprehensive introductions to Qur'ānic Studies.

2 Notwithstanding the controversies as to if the Prophet mastered the technology of reading scripture, reading must here be understood more widely than mastering the art of decoding a particular set of symbols (Günther, 2002).

3 Translations are taken from Abdel Haleem 2004.

${ }^{4}$ For an overview of topics in the Qur'ān, see McAuliffe 2001-2006, Rahman 2009.

${ }^{5}$ On translation of the Qur'ann into the local contexts discussed in the articles in this special issue, Sweden, Denmark and Norway, see an overview in Eggen 2019.

\section{References}

Abdel Haleem, M. A. S. (Trans.). (2004) The Qur'an: A New Translation. Oxford: Oxford University Press.

Campanini, M. (2007). The Qur'an. The Basics (Oliver Leaman, Trans.). London/New York: Routledge.

Eggen, N. S. (2016). Universalised versus particularised conceptualisations of Islam in translations of the Qur'ān, Journal of Qur'ānic Studies, 1(1), 1-43.

Eggen, N. S. (forthcoming 2019). On the Periphery: Translations of the Qur'ān in Sweden, Denmark and Norway. In A. W. Khalifa, S. H. Soliman, \& H. El-Farahaty (Eds.), Routledge Handbook of Arabic Translation (pp. 65-80). London: Routledge.

Günther, S. (2002). Muhammad, the illiterate Prophet: An Islamic Creed in the Qur'an and Qur'anic Exegesis. Journal of Qur'anic Studies 4(1), 1-26.

McAuliffe, J. D. (Ed.). (2006). The Cambridge companion to the Qur'ān. Cambridge: Cambridge University Press.

McAuliffe, J. D. (Ed.). (2001-2006). Encyclopaedia of the Qur'ān. 6 vols. Leiden: Brill. Also available with updates at Brill Online: http://referenceworks.brillonline.com/ browse/encyclopaedia-of-the-quran

Neuwirth, A. (2019). The Qur'an and Late Antiquity: A Shared Heritage (Samuel Wilder, Trans.). Oxford: Oxford University Press.

Rahman, F (2009). Major Themes of the Qur'an (2nd ed.). Chicago: The University of Chicago Press.

Rippin, A., \& Mojaddedi, J. (Eds.). (2017). The Blackwell Companion to the Qur'ān (2nd ed.). Malden: Wiley-Blackwell.

Shah, M., \& Abdel Haleem M. A. S. (Eds). (forthcoming 2019). The Oxford Handbook of Qur'anic Studies. Oxford: Oxford University Press.

al-Zarkashī, B. M. (1994). al-Burhān fì 'ulūm al-Qur'ān (Y. 'A. al-Mara'shalī, Ed.). 4 vols. Beirut: Dār al-ma'rifa. 